\title{
Prevalence of Specific Multimorbidity Combinations and Association with Medical Expenditures and Perceived Health among U.S. Adults, 2016-2019
}

Nicholas K. Schiltz, $\mathrm{PhD}^{1,2,3}$

(1) Frances Payne Bolton School of Nursing, Case Western Reserve University, Cleveland, Ohio; (2) Department of Population \& Quantitative Health Sciences, Case Western Reserve University School of Medicine, Cleveland, Ohio; (3) Center for Community Health Integration, Case Western Reserve University School of Medicine, Cleveland, Ohio

Word count: 2,028

Corresponding Author:

Nicholas K. Schiltz, PhD

Frances Payne Bolton School of Nursing

Case Western Reserve University

10900 Euclid Avenue

Cleveland, Ohio 44106-7343

Phone: 216-368-5626

Email:nks8@case.edu 


\section{ABSTRACT}

IMPORTANCE: Multimorbidity is common, but the prevalence and outcomes of the specific combinations of co-occurring disease has not been systematically examined in the general U.S. adult population.

OBJECTIVE: To identify and measure the burden of highly prevalent combinations of chronic conditions that are treated among adults 18 and older in the United States.

DESIGN: Cross-sectional analysis of the Medical Expenditure Panel Survey (MEPS), 20162019.

SETTING: U.S. households

PARTICIPANTS: Nationally-representative sample of civilian non-institutionalized adults 18 and older $(n=89,947)$.

MEASUREMENTS: Multimorbidity - defined as any combination of 20 different self-reported chronic conditions treated during the study period. Frequent pattern mining and association rule mining were used to identify the most common combinations of multimorbidity that met a threshold of occurring in at least one million subjects of the weighted study population. The main measures and outcomes were annual self-reported prevalence, total medical expenditures, and perceived fair/poor health. Generalized linear regression was used to estimate age-race-sex adjusted odds ratios for perceived health. Taylor series estimation produced weighted estimates and $95 \%$ confidence intervals.

RESULTS: An estimated $32.9 \%$ of the US population is treated for two or more chronic conditions annually. Frequent pattern mining yielded 259 unique combinations of chronic disease, including 77 two-way (dyad), 134 three-way (triad), 47 four-way, and one five-way combinations that affect one million or more of the weighted study population. An estimated 30.8 million people or $12.4 \%(95 \% \mathrm{Cl}$ : $12.0-12.7 \%)$ of the U.S. adult population is treated for at least $\{$ Hypertension \& Hyperlipidemia\} - the most common two-way combination. The 
medRxiv preprint doi: https://doi.org/10.1101/2022.01.18.22269483; this version posted January 21, 2022. The copyright holder for this preprint

(which was not certified by peer review) is the author/funder, who has granted medRxiv a license to display the preprint in perpetuity.

It is made available under a CC-BY-NC-ND 4.0 International license.

combination of $\{$ Diabetes \& Arthritis \& Cardiovascular disease $\}$ was associated with the highest median annual medical expenditures (\$23,850, [Interquartile range: $\$ 11,593-\$ 44,616])$, and the combination of $\{$ Diabetes \& Arthritis \& Asthma/COPD $\}$ had the highest age-race-sex adjusted odds ratio of fair/poor self-rated health (adjusted odd ratio: 6.9, [95\%Cl: $5.4-8.8]$ ). CONCLUSION: This study demonstrates the many combinations of disease are highly prevalent in the population. However, most research and clinical practice guidelines are singledisease focused. The combinations reported here could be prioritized for evidence-based research, especially those most associated with poor health and high medical costs. 


\section{INTRODUCTION}

An estimated $42 \%$ percent of American adults suffer from multiple chronic conditions (i.e. multimorbidity). ${ }^{1}$ Persons with multimorbidity are at higher mortality rates, lower healthrelated quality life, increased healthcare use, and are at higher risk for many poor health outcome events including adverse drug events. ${ }^{2-6}$ While numerous data exist on the prevalence of single chronic conditions ${ }^{1,7}$, much less is known about the prevalence of specific combinations of multimorbidity. Most prevalence studies of multimorbidity are based on counts of conditions. ${ }^{8,9}$ Studies that have examined the prevalence of specific combinations of multimorbidity in the US have been mostly limited to dyad and triad combinations ${ }^{10-12}$ or a small number of conditions, ${ }^{13,14}$ or conducted in a specific sub-populations ${ }^{15}$ or limited to older adults. ${ }^{13,16}$

The prevalence of specific combinations of multimorbidity of the general communitydwelling adult population has not been established comprehensively in the United States. The US Department of Health and Human Services' strategic framework on multimorbidity identified understanding the epidemiology of constellations of multiple chronic conditions as one of its top research goals. ${ }^{17}$ More recently, the Academy of Medical Sciences listed identifying trends and patterns of multimorbidity, and the specific clusters that cause the greatest burden as its top two goals in multimorbidity research. ${ }^{18}$ Evidence about which conditions most commonly co-occur together and their impact on outcomes can help inform decisions about how to optimize prevention and treatment strategies, and design health systems to offer more holistic care rather the usual practice of treating one condition at a time. ${ }^{18}$ Further, measuring the impact of multimorbidity based on counts of conditions or weighted scores may miss important heterogeneity, because the specific combinations of chronic disease matter in terms of health outcomes ${ }^{19}$ including mortality and poor health, ${ }^{5}$ ADL/IADL limitations, ${ }^{14,20}$ and cost and utilization. ${ }^{6}$ 
The goal of this study was to identify and rank the most frequent multi-way (two-way, three-way, four-way, etc...) combinations of multimorbidity treated among adults in the United States. Innovative machine learning algorithms - frequent pattern mining and association rule learning - were used to identify all combinations of multimorbidity occurring in one million or more U.S. adults. The association of these combinations with average per capita direct medical expenditures and perceived fair or poor health status was also examined.

\section{METHODS}

This study was a cross-sectional analysis of the 2016 - 2019 Medical Expenditure Panel Survey Household Component (MEPS). The MEPS is a large-scale panel survey of a nationally representative sample of households in the United States and is administered by the Agency for Healthcare Research and Quality (AHRQ). ${ }^{21}$ The MEPS collects data at the person-level on numerous topics including medical expenditures, utilization, medical conditions, health status, and demographics. Interviews are conducted in-person using computer-assisted personal interview (CAPI) technology.

This study included all adults age 18 and older with non-zero weights. Subjects with missing data on self-reported health or expenditures were excluded $(n \leq 10)$. The final unweighted sample was 89,947 adults. This study was determined to be Not Human Subjects Research by the author's Institutional Review Board (\#NHR-15-48).

Health conditions are self-reported through open-ended questions about conditions reported to be associated with health care events. ${ }^{22}$ The respondents verbatim text responses are coded according to the International Classification of Diseases, Tenth Revision, Clinical Modification (ICD-10-CM). Treatment of these conditions may have been received through inpatient stays, outpatient or office-based visits, emergency department visits, home health care, or prescribed medications. Chronic conditions were then classified into one of 20 primary 
care relevant chronic conditions used in recent studies of multimorbidity. ${ }^{23,24} \mathrm{~A}$ list of each chronic condition categories and corresponding ICD-10-CM codes is included in the appendix (eTable 1).

Perceived health was assessed by asking respondents to rate their health as excellent (1), very good (2), good (3), fair (4), or poor (5). A response of fair or poor was categorized as "poor perceived health."

Medical expenditures are defined as the sum of direct payments for care provided during the year, including out-of-pocket payments and payments by private insurance, Medicaid, Medicare, and other sources. Expenditure data are collected through both self-report and through data collected from the respondents' physicians, hospitals, and pharmacies, when available. Imputation is used when data are missing or payments are made under capitated plans. ${ }^{22}$ Expenditures were adjusted for annual inflation and are reported in terms of 2019 dollars using the Personal Consumption Expenditure Health Price Index from the Bureau of Economic Analysis. ${ }^{25}$

\section{Statistical Analysis and Measures:}

Association Rule Mining (ARM) was used to identify the frequent multi-way combinations of chronic disease. ${ }^{26} \mathrm{ARM}$ is a machine learning method originally developed by computer scientists to find items commonly purchased together in the same transaction (also called market-basket analysis), but has since been extended to other applications, including medicine and bioinformatics (cites; Brin, 1997, other examples). ${ }^{15,27-29}$ The method was applied here by treating each subject in the study data as the "transaction," and each chronic condition as the "items" to find the most frequently co-occurring combinations. As there are $1,048,576\left(2^{20}\right)$ possible combinations of 20 conditions, ARM uses the Apriori algorithm and a minimum prevalence or "support" threshold to trim the search space and make it computationally feasible. 
In brief, the Apriori algorithm states that if a given combination is below the minimum support threshold, then all of the supersets (the combination + one or more additional conditions) are also below the threshold. The minimum support is defined by the user; it was set at $0.20 \%$ for the initial pass, and then after applying survey weights, any combinations with a point estimate of less than one million adults ( $0.40 \%$ of the U.S. adult population) was dropped.

The MEPS uses a complex stratified random sampling design. Design-based survey methods (i.e. Taylor series estimation) were used to account for stratification and clustering effects when estimating variances. Survey weights were divided by four to produce all study results in terms of annual values. Person-level weights were applied to get the average annual estimated number and percent of persons with a disease combination and $95 \%$ confidence interval. The median and average annual per capita medical expenditures and percent selfreporting fair/poor health status was calculated for each combination after applying weights.

When ranking combinations by expenditures or poor health, a minimum improvement criteria of $10 \%$ was set to filter out rules that are redundant or offer little new information on the outcome measure over more parsimonious combinations. ${ }^{30,31}$ The age-race-sex adjusted odds ratio of fair/poor health status was estimated for each disease combination using survey weighted generalized linear regression with a logit link function. The adjustment variables were age as a continuous variable with splines, race (Hispanic, non-Hispanic white, non-Hispanic black, non-Hispanic Asian, and other), and sex.

Data pre-processing was performed using SAS version 9.4 for Windows. The analysis was conducted using R version 4.1.0, RStudio (v. 1.4.1717), and R packages: arules (v. 1.6-8) and survey (v. 4.1-1). ${ }^{32,33}$

\section{RESULTS}


medRxiv preprint doi: https://doi.org/10.1101/2022.01.18.22269483; this version posted January 21, 2022. The copyright holder for this preprint (which was not certified by peer review) is the author/funder, who has granted medRxiv a license to display the preprint in perpetuity.

It is made available under a CC-BY-NC-ND 4.0 International license .

The total weighted study population was 249.2 million adults age 18 and older, with 82.0 million (32.9\%) reporting receiving treatment for two or more conditions (Table 1) in a single year. 51.7 million (20.7\%) adults have three or more conditions, and 30.6 million (12.3\%) have 4 or more conditions. A dose response increase is evident between number of chronic conditions and the percentage reporting fair/poor perceived health and average annual medical expenditures.

Frequent pattern mining yielded 259 unique combinations of chronic disease, including 77 two-way, 134 three-way, 47 four-way, and one five-way combinations that affect one million or more of the weighted study population. The top 25 of these multi-way combinations, ranked by prevalence are shown in Table 2 , and the full table is included in supplement (eTable 2). There are eight combinations that affect 10 million or more adults, 32 combinations that affect 5 million or more adults, and 129 that affect 2 million or more adults per year. There were not any six-way or higher combinations that met the minimum prevalence threshold.

Combinations of conditions and corresponding prevalence estimates represent "at least", rather than "exactly." For example, an estimated 31.5 million people $(12.7 \%, 95 \% \mathrm{Cl}$ : 12.2\% $13.3 \%$ ) of the U.S. adult population are treated for at least hypertension \& hyperlipidemia - the most common combination (Table 1). An estimated 19.3 million people $(4.8 \%, 95 \% \mathrm{Cl}: 4.5 \%-$ $5.2 \%)$ have at least hypertension \& hyperlipidemia \& arthritis - the most common 3-way combination, and fifth most common combination overall. These 12.0 million are a subset of the 31.5 million with at least hypertension \& hyperlipidemia.

The combination \{Diabetes \& Urinary problems \& Cardiovascular disease\} had the highest average annual medical expenditures per capita $(\$ 35,782,95 \% \mathrm{Cl}$ : $\$ 31,129-\$ 40,435)$ among combinations of disease affecting one million or more adults (Table 3). This was 2.1 times higher than the average for having any three or more chronic conditions $(\$ 16,819)$, and was also at least $23.1 \%$ higher than the average expenditures for any single or two-way 
medRxiv preprint doi: https://doi.org/10.1101/2022.01.18.22269483; this version posted January 21, 2022. The copyright holder for this preprint (which was not certified by peer review) is the author/funder, who has granted medRxiv a license to display the preprint in perpetuity.

It is made available under a CC-BY-NC-ND 4.0 International license .

combinations of those three disease alone. Average expenditures were higher than median expenditures across the board, indicating the right-skewed nature of expenditures. The combination of $\{$ Diabetes \& Arthritis \& Cardiovascular disease $\}$ had the highest median annual expenditures per capita (\$23,850, Interquartile range: $\$ 11,593-\$ 44,616)$.

The combination of $\{$ Diabetes \& Asthma/COPD \& Cardiovascular disease $\}$ was also most associated with perceived poor health status with an adjusted odds ratio of $6.9(5.4-8.8)$ (Table 3). The $62.9 \%$ reporting fair/poor health was at least $12.6 \%$ higher than any single or two-way combination of those three diseases, and was 2.1 times higher than the average percent reporting fair/poor health among those with any three or more chronic conditions.

\section{DISCUSSION}

This study combined data mining with survey epidemiology to comprehensively identify and estimate the treatment prevalence of the most frequent combinations of multimorbidity in the United States. This analysis showed that certain multimorbidity combinations of disease are quite common in the US, occurring in one million or more adults. Despite this, most evidencebased practice guidelines are single-disease focused, and few, if any, clinical trials have been conducted on the optimal care management for most of these multimorbidity combinations. ${ }^{6}$ The highly prevalent combinations reported here could be prioritized for future observational and intervention studies.

This study has several strengths. First, it represents the most comprehensive attempt to identify the prevalence of multimorbidity combinations in the general adult population in the United States. A nationally representative sample was used to identify the combinations and estimate the prevalence using survey-weighted techniques. The MEPS database is also unique in its condition enumeration approach, which allows for a more comprehensive capture of different chronic conditions. While most national surveys only ask questions on a fixed number 
medRxiv preprint doi: https://doi.org/10.1101/2022.01.18.22269483; this version posted January 21, 2022. The copyright holder for this preprint (which was not certified by peer review) is the author/funder, who has granted medRxiv a license to display the preprint in perpetuity.

It is made available under a CC-BY-NC-ND 4.0 International license .

of diseases, the MEPS uses open-ended responses and reconciliation between utilization records. Administrative sources like claims data would also be able to capture a comprehensive set of conditions, but these would be limited to patients for a given payer and would not capture the uninsured. Electronic health records are typically limited to a single health care system, and are not nationally-representative. Association rule mining allows for the identification of highly prevalent combinations in a quick and computationally efficient manner, while filtering out combinations that are sparse. While this study focuses on highly prevalent combinations occurring in over 1 million adults, the method could be used to identify higher order combinations by setting a lower prevalence thresholds.

This study also has several limitations. The MEPS provides accurate estimates of treated prevalence for chronic disease, but this is likely lower than the underlying population prevalence for some conditions. ${ }^{22}$ On the other hand, the focus on treated conditions represent those for which care decisions between multiple conditions may conflict. The MEPS includes community-dwelling subjects only, meaning institutionalized persons such as nursing home and assisted living residents are excluded. Estimates of total expenditures are typically lower than what is estimated from the National Health Expenditure Accounts (NHEA), because the MEPS does not include these institutionalized populations. ${ }^{34}$ ICD-10 codes were classified into 20 primary-care relevant conditions using an established algorithm, but other classification systems may result in different combinations and prevalence estimates.

\section{CONCLUSION}

This cross-sectional analysis of a nationally-representative survey showed that certain multimorbidity combinations of disease are quite common in the US, occurring in one million or more adults. The combinations reported here could be prioritized for evidence-based research and integration into practice guidelines, especially those most associated with poor health and high medical costs. 
medRxiv preprint doi: https://doi.org/10.1101/2022.01.18.22269483; this version posted January 21, 2022. The copyright holder for this preprint (which was not certified by peer review) is the author/funder, who has granted medRxiv a license to display the preprint in perpetuity.

It is made available under a CC-BY-NC-ND 4.0 International license. 
medRxiv preprint doi: https://doi.org/10.1101/2022.01.18.22269483; this version posted January 21, 2022. The copyright holder for this preprint (which was not certified by peer review) is the author/funder, who has granted medRxiv a license to display the preprint in perpetuity. It is made available under a CC-BY-NC-ND 4.0 International license.

\section{Funding and Acknowledgements:}

Dr. Schiltz had full access to all of the data in the study and takes responsibility for the integrity of the data and the accuracy of the data analysis. The author of this report has no conflicts of interest to disclose. This project was supported in part by $\mathrm{NIH/NCATS} \mathrm{CTSA} \mathrm{KL2TR0002547.} \mathrm{Its} \mathrm{contents} \mathrm{are} \mathrm{solely} \mathrm{the} \mathrm{responsibility} \mathrm{of} \mathrm{the}$ author and do not necessarily represent the official views of the $\mathrm{NIH}$. The author would like to thank Obada Farhan, MS (Case Western Reserve University) and R. Henry Olaisen for their roles in writing some of the R code used in the analysis, and Kurt Stange, MD, PhD for his mentorship on the career development award that supported this work. 
medRxiv preprint doi: https://doi.org/10.1101/2022.01.18.22269483; this version posted January 21, 2022. The copyright holder for this preprint (which was not certified by peer review) is the author/funder, who has granted medRxiv a license to display the preprint in perpetuity. It is made available under a CC-BY-NC-ND 4.0 International license .

\section{REFERENCES}

1. Buttorff C, Ruder T, Bauman M. Multiple Chronic Conditions in the United States. RAND Corporation; 2017. Accessed October 5, 2019. https://www.rand.org/pubs/tools/TL221.html

2. Fortin M, Bravo G, Hudon C, et al. Relationship between multimorbidity and health-related quality of life of patients in primary care. Qual Life Res Int J Qual Life Asp Treat Care Rehabil. 2006;15(1):83-91. doi:10.1007/s11136-005-8661-z

3. Gijsen R, Hoeymans N, Schellevis FG, Ruwaard D, Satariano WA, van den Bos GA. Causes and consequences of comorbidity: a review. J Clin Epidemiol. 2001;54(7):661-674. doi:10.1016/s0895-4356(00)00363-2

4. Wolff JL, Starfield B, Anderson G. Prevalence, expenditures, and complications of multiple chronic conditions in the elderly. Arch Intern Med. 2002;162(20):2269-2276.

doi:10.1001/archinte.162.20.2269

5. Koroukian SM, Schiltz N, Warner DF, et al. Combinations of Chronic Conditions, Functional Limitations, and Geriatric Syndromes that Predict Health Outcomes. J Gen Intern Med. 2016;31(6):630-637. doi:10.1007/s11606-016-3590-9

6. Schiltz NK, Warner DF, Sun J, et al. Identifying Specific Combinations of Multimorbidity that Contribute to Health Care Resource Utilization: An Analytic Approach. Med Care. 2017;55(3):276-284. doi:10.1097/MLR.0000000000000660

7. James SL, Abate D, Abate $\mathrm{KH}$, et al. Global, regional, and national incidence, prevalence, and years lived with disability for 354 diseases and injuries for 195 countries and territories, 1990-2017: a systematic analysis for the Global Burden of Disease Study 2017. The Lancet. 2018;392(10159):1789-1858. doi:10.1016/S0140-6736(18)32279-7

8. Fortin M, Stewart M, Poitras ME, Almirall J, Maddocks H. A Systematic Review of Prevalence Studies on Multimorbidity: Toward a More Uniform Methodology. Ann Fam Med. 2012;10(2):142-151. doi:10.1370/afm.1337

9. Salive ME. Multimorbidity in Older Adults. Epidemiol Rev. 2013;35(1):75-83. doi:10.1093/epirev/mxs009

10. Lochner KA, Cox CS. Prevalence of multiple chronic conditions among Medicare beneficiaries, United States, 2010. Prev Chronic Dis. 2013;10:E61. doi:10.5888/pcd10.120137

11. Steinman MA, Lee SJ, Boscardin WJ, et al. Patterns of Multimorbidity in Elderly Veterans. J Am Geriatr Soc. 2012;60(10):1872-1880. doi:10.1111/j.1532-5415.2012.04158.x

12. Garin N, Koyanagi A, Chatterji S, et al. Global Multimorbidity Patterns: A Cross-Sectional, Population-Based, Multi-Country Study. J Gerontol A Biol Sci Med Sci. 2016;71(2):205214. doi:10.1093/gerona/glv128

13. Weiss CO, Boyd CM, Yu Q, Wolff JL, Leff B. Patterns of Prevalent Major Chronic Disease Among Older Adults in the United States. JAMA. 2007;298(10):1158-1162. doi:10.1001/jama.298.10.1160-b 
medRxiv preprint doi: https://doi.org/10.1101/2022.01.18.22269483; this version posted January 21, 2022. The copyright holder for this preprint (which was not certified by peer review) is the author/funder, who has granted medRxiv a license to display the preprint in perpetuity.

It is made available under a CC-BY-NC-ND 4.0 International license .

14. Quiñones AR, Markwardt S, Botoseneanu A. Multimorbidity Combinations and Disability in Older Adults. J Gerontol A Biol Sci Med Sci. 2016;71(6):823-830.

doi:10.1093/gerona/glw035

15. Held FP, Blyth F, Gnjidic D, et al. Association Rules Analysis of Comorbidity and Multimorbidity: The Concord Health and Aging in Men Project. J Gerontol A Biol Sci Med Sci. 2016;71(5):625-631. doi:10.1093/gerona/glv181

16. Koroukian SM, Schiltz NK, Warner DF, et al. Multimorbidity: constellations of conditions across subgroups of midlife and older individuals, and related Medicare expenditures. $J$ Comorbidity. 2017;7(1):33-43. doi:10.15256/joc.2017.7.91

17. Parekh AK, Goodman RA, Gordon C, Koh HK. Managing Multiple Chronic Conditions: A Strategic Framework for Improving Health Outcomes and Quality of Life. Public Health Rep. 2011;126(4):460-471. doi:10.1177/003335491112600403

18. Academy of Medical Sciences. Multimorbidity: A Priority for Global Health Research.; 2018. Accessed October 3, 2019. https://acmedsci.ac.uk/policy/policyprojects/multimorbidity

19. Vogeli C, Shields AE, Lee TA, et al. Multiple chronic conditions: prevalence, health consequences, and implications for quality, care management, and costs. $J$ Gen Intern Med. 2007;22 Suppl 3:391-395. doi:10.1007/s11606-007-0322-1

20. Quiñones AR, Markwardt S, Thielke S, Rostant O, Vásquez E, Botoseneanu A. Prospective Disability in Different Combinations of Somatic and Mental Multimorbidity. $J$ Gerontol Ser A. 2018;73(2):204-210. doi:10.1093/gerona/glx100

21. Cohen J. Methodology Report \#1: Design and Methods of the Medical Expenditure Panel Survey Household Component. Agency for Health Care Policy and Research; 1997. Accessed October 26, 2014. http://meps.ahrq.gov/data_files/publications/mr1/mr1.shtml

22. Machlin S, Cohen J, Elixhauser A, Beauregard K, Steiner C. Sensitivity of Household Reported Medical Conditions in the Medical Expenditure Panel Survey: Med Care. 2009;47(6):618-625. doi:10.1097/MLR.0b013e318195fa79

23. Nicholson K, Bauer M, Terry AL, Fortin M, Williamson T, Thind A. The multimorbidity cluster analysis tool: identifying combinations and permutations of multiple chronic diseases using a record-level computational analysis. BMJ Health Care Inform. 2017;24(4):339-343. doi:10.14236/jhi.v24i4.962

24. Nicholson K, Terry AL, Fortin M, Williamson T, Bauer M, Thind A. Prevalence, characteristics, and patterns of patients with multimorbidity in primary care: a retrospective cohort analysis in Canada. Br J Gen Pract. 2019;69(686):e647-e656. doi:10.3399/bjgp19X704657

25. Dunn A, Grosse SD, Zuvekas SH. Adjusting Health Expenditures for Inflation: A Review of Measures for Health Services Research in the United States. Health Serv Res.

2018;53(1):175-196. doi:10.1111/1475-6773.12612 
medRxiv preprint doi: https://doi.org/10.1101/2022.01.18.22269483; this version posted January 21, 2022. The copyright holder for this preprint

(which was not certified by peer review) is the author/funder, who has granted medRxiv a license to display the preprint in perpetuity.

It is made available under a CC-BY-NC-ND 4.0 International license .

26. Agrawal R, Srikant R. Fast algorithms for mining association rules. In: Proc. of 20th Intl. Conf. on VLDB. ; 1994:487-499.

27. Brin S, Motwani R, Ullman JD, Tsur S. Dynamic Itemset Counting and Implication Rules for Market Basket Data. In: Proceedings of the 1997 ACM SIGMOD International Conference on Management of Data. SIGMOD '97. ACM; 1997:255-264. doi:10.1145/253260.253325

28. Zemedikun DT, Gray LJ, Khunti K, Davies MJ, Dhalwani NN. Patterns of Multimorbidity in Middle-Aged and Older Adults: An Analysis of the UK Biobank Data. Mayo Clin Proc.

2018;93(7):857-866. doi:10.1016/j.mayocp.2018.02.012

29. Zheng C, Xu R. The Alzheimer's comorbidity phenome: mining from a large patient database and phenome-driven genetics prediction. JAMIA Open. 2019;2(1):131-138. doi:10.1093/jamiaopen/ooy050

30. Ho VP, Schiltz NK, Reimer AP, Madigan EA, Koroukian SM. High-Risk Comorbidity Combinations in Older Patients Undergoing Emergency General Surgery: COMORBIDITY COMBINATIONS IN EMERGENCY SURGERY. J Am Geriatr Soc. 2019;67(3):503-510. doi:10.1111/jgs.15682

31. Bayardo RJ, Agrawal R, Gunopulos D. Constraint-based rule mining in large, dense databases. In: Proceedings 15th International Conference on Data Engineering (Cat. No.99CB36337). IEEE; 1999:188-197. doi:10.1109/ICDE.1999.754924

32. Hahsler M, Buchta C, Gruen B, Hornik K, Borgelt C. Arules: Mining Association Rules and Frequent Itemsets.; 2016. Accessed January 31, 2017. https://cran.rproject.org/web/packages/arules/index.html

33. Lumley T. Analysis of complex survey samples. J Stat Softw. 2004;9(1):1-19.

34. Bernard D, Cowan C, Selden T, Cai L, Catlin A, Heffler S. Reconciling medical expenditure estimates from the MEPS and NHEA, 2007. Medicare Medicaid Res Rev.

2012;2(4):mmrr.002.04.a09. doi:10.5600/mmrr.002.04.a09 
Table 1: Number of Chronic Conditions among U.S. Adults by Population Characteristics, 2016-2019

\begin{tabular}{|c|c|c|c|c|c|c|c|}
\hline Variable & $\begin{array}{c}\text { No. in } \\
\text { unweighted } \\
\text { sample }\end{array}$ & $\begin{array}{l}\text { Weighted No. } \\
\text { of Adults }\end{array}$ & $\begin{array}{c}0 \text { chronic } \\
\text { conditions, } \\
\text { Row \% }\end{array}$ & $\begin{array}{c}\text { 1+ chronic } \\
\text { conditions, } \\
\text { Row } \%\end{array}$ & $\begin{array}{c}2+\text { chronic } \\
\text { conditions, } \\
\text { Row } \%\end{array}$ & $\begin{array}{l}\text { 3+ chronic } \\
\text { conditions, } \\
\text { Row } \%\end{array}$ & $\begin{array}{l}\text { 4+ chronic } \\
\text { conditions, } \\
\text { Row } \%\end{array}$ \\
\hline Total & 89,947 & $249,221,000$ & $47.4 \%$ & $52.6 \%$ & $32.9 \%$ & $20.7 \%$ & $12.3 \%$ \\
\hline \multicolumn{8}{|l|}{ Age Group } \\
\hline $18-39$ & 17,745 & $94,573,000$ & $73.9 \%$ & $26.1 \%$ & $7.9 \%$ & $2.7 \%$ & $0.9 \%$ \\
\hline $40-64$ & 19,776 & $102,614,000$ & $41.1 \%$ & $58.9 \%$ & $35.5 \%$ & $20.0 \%$ & $10.6 \%$ \\
\hline 65 and older & 9,311 & $52,034,000$ & $11.6 \%$ & $88.4 \%$ & $73.0 \%$ & $54.9 \%$ & $36.1 \%$ \\
\hline \multicolumn{8}{|l|}{ Sex } \\
\hline Male & 21,671 & $120,330,000$ & $52.4 \%$ & $47.6 \%$ & $29.9 \%$ & $18.8 \%$ & $10.7 \%$ \\
\hline Female & 25,161 & $128,891,000$ & $42.7 \%$ & $57.3 \%$ & $35.7 \%$ & $22.5 \%$ & $13.7 \%$ \\
\hline \multicolumn{8}{|l|}{ Race / Ethnicity } \\
\hline Hispanic & 12,841 & $40,533,000$ & $63.3 \%$ & $36.7 \%$ & $19.5 \%$ & $11.6 \%$ & $6.2 \%$ \\
\hline Non-Hispanic White only & 21,164 & $156,551,000$ & $40.7 \%$ & $59.3 \%$ & $38.4 \%$ & $24.5 \%$ & $14.9 \%$ \\
\hline Non-Hispanic Black only & 8,113 & $29,523,000$ & $53.0 \%$ & $47.0 \%$ & $28.9 \%$ & $18.0 \%$ & $10.1 \%$ \\
\hline Non-Hispanic Asian only & 3,355 & $15,133,000$ & $62.4 \%$ & $37.6 \%$ & $20.0 \%$ & $11.3 \%$ & $5.4 \%$ \\
\hline Other or Multiple Race & 1,359 & $7,481,000$ & $47.8 \%$ & $52.2 \%$ & $32.7 \%$ & $21.0 \%$ & $12.8 \%$ \\
\hline Self-rated Fair/Poor Health & 7,201 & $31,085,000$ & $19.0 \%$ & $81.0 \%$ & $64.6 \%$ & $48.8 \%$ & $34.3 \%$ \\
\hline $\begin{array}{l}\text { Per capita medical expenditures } \\
\text { in } 2019 \text { dollars (Median, IQR) }\end{array}$ & --- & --- & $\begin{array}{r}\$ 322 \\
(\$ 0- \\
\$ 1,382)\end{array}$ & $\begin{array}{r}\$ 4,176 \\
(\$ 1,523- \\
\$ 11,067)\end{array}$ & $\begin{array}{r}\$ 6,208 \\
(\$ 2,558- \\
\$ 14,858)\end{array}$ & $\begin{array}{r}\$ 8,177 \\
(\$ 3,610- \\
\$ 18,756)\end{array}$ & $\begin{array}{c}\$ 10,821 \\
(\$ 5,045- \\
\$ 23,712)\end{array}$ \\
\hline
\end{tabular}

Table 1 caption: Survey-weighted estimates from pooling the 2016-2019 Medical Expenditure Panel Survey. Weighted estimates have been annualized by taking the average over the four year study period. Row percentages are reported under each count of conditions column. 
Table 2: Combinations of Multimorbidity among U.S. Adults, Ranked by Treated Prevalence, 2016 - 2019

\begin{tabular}{|c|c|c|c|c|c|c|}
\hline Rank & Combination of Chronic Disease & $\begin{array}{l}\text { No. of } \\
\text { cond- } \\
\text { itions }\end{array}$ & $\begin{array}{c}\text { No. in } \\
\text { unweighted } \\
\text { sample }\end{array}$ & $\begin{array}{l}\text { Weighted } \\
\text { No. of } \\
\text { Adults (in } \\
\text { millions) }\end{array}$ & $\begin{array}{l}\text { Prevalence, \% } \\
\quad(95 \% \text { CI })\end{array}$ & $\begin{array}{c}\text { Observed to } \\
\text { Expected Ratio } \\
(95 \% \text { CI })\end{array}$ \\
\hline 1 & Hypertension \& Hyperlipidemia & 2 & 11,967 & 30.80 & $12.4(12.0-12.8)$ & $2.7(2.6-2.7)$ \\
\hline 2 & Hypertension \& Diabetes & 2 & 6,980 & 16.54 & $6.6(6.4-6.9)$ & $2.6(2.5-2.7)$ \\
\hline 3 & Hypertension \& Musculoskeletal condition & 2 & 5,681 & 14.53 & $5.8(5.6-6.1)$ & $1.6(1.6-1.7)$ \\
\hline 4 & Hyperlipidemia \& Diabetes & 2 & 5,911 & 14.28 & $5.7(5.5-6.0)$ & $3.1(3.0-3.2)$ \\
\hline 5 & Hypertension \& Hyperlipidemia \& Diabetes & 3 & 4,821 & 11.51 & $4.6(4.4-4.9)$ & $9.5(9.3-9.8)$ \\
\hline 6 & Hyperlipidemia \& Musculoskeletal condition & 2 & 4,315 & 11.28 & $4.5(4.3-4.7)$ & $1.7(1.6-1.8)$ \\
\hline 7 & Hypertension \& Arthritis & 2 & 4,390 & 10.70 & $4.3(4.1-4.5)$ & $2.3(2.3-2.4)$ \\
\hline 8 & Hypertension \& Stomach problems & 2 & 4,004 & 10.01 & $4.0(3.8-4.3)$ & $2.3(2.2-2.4)$ \\
\hline 9 & Hypertension \& Cardiovascular disease & 2 & 3,815 & 9.81 & $3.9(3.7-4.1)$ & $2.7(2.6-2.8)$ \\
\hline 10 & Hypertension \& Urinary problems & 2 & 3,552 & 9.11 & $3.7(3.5-3.8)$ & $2.0(2.0-2.1)$ \\
\hline 11 & Hypertension \& Asthma/COPD & 2 & 3,494 & 8.83 & $3.5(3.3-3.8)$ & $1.8(1.7-1.8)$ \\
\hline 12 & Hypertension \& Thyroid disorder & 2 & 3,309 & 8.79 & $3.5(3.3-3.7)$ & $1.8(1.7-1.8)$ \\
\hline 13 & Hyperlipidemia \& Cardiovascular disease & 2 & 3,235 & 8.54 & $3.4(3.2-3.6)$ & $3.2(3.1-3.3)$ \\
\hline 14 & Hyperlipidemia \& Arthritis & 2 & 3,371 & 8.43 & $3.4(3.2-3.6)$ & $2.5(2.4-2.6)$ \\
\hline 15 & Hyperlipidemia \& Stomach problems & 2 & 3,199 & 8.08 & $3.2(3.0-3.4)$ & $2.5(2.4-2.6)$ \\
\hline 16 & Hypertension \& Depression/Anxiety & 2 & 3,010 & 7.89 & $3.2(3.0-3.4)$ & $1.5(1.4-1.6)$ \\
\hline 17 & $\begin{array}{l}\text { Hypertension \& Hyperlipidemia \& } \\
\text { Musculoskeletal condition }\end{array}$ & 3 & 3,103 & 7.87 & $3.2(3.0-3.3)$ & $4.7(4.5-4.8)$ \\
\hline 18 & Musculoskeletal condition \& Arthritis & 2 & 2,916 & 7.53 & $3.0(2.9-3.2)$ & $2.7(2.6-2.9)$ \\
\hline 19 & Hyperlipidemia \& Thyroid disorder & 2 & 2,753 & 7.42 & $3.0(2.8-3.2)$ & $2.0(2.0-2.1)$ \\
\hline 20 & Hyperlipidemia \& Urinary problems & 2 & 2,827 & 7.34 & $2.9(2.8-3.1)$ & $2.2(2.1-2.3)$ \\
\hline 21 & $\begin{array}{l}\text { Hypertension \& Hyperlipidemia \& Cardiovascular } \\
\text { disease }\end{array}$ & 3 & 2,651 & 6.82 & $2.7(2.6-2.9)$ & $\begin{array}{r}10.0(9.6- \\
10.4)\end{array}$ \\
\hline 22 & Hyperlipidemia \& Asthma/COPD & 2 & 2,588 & 6.68 & $2.7(2.5-2.8)$ & $1.8(1.7-1.9)$ \\
\hline 23 & Hypertension \& Hyperlipidemia \& Arthritis & 3 & 2,659 & 6.45 & $2.6(2.4-2.8)$ & $7.5(7.2-7.8)$ \\
\hline
\end{tabular}


Table 2 Caption: Top 25 multi-way combinations of chronic disease ranked by prevalence from the 2016-2019 Medical Expenditure Panel Survey (MEPS). Weighted number and percent and 95\% confidence intervals were calculated by applying population weights using Taylor-series methods (i.e. complex survey methods) to account for the complex sampling design of the MEPS. Weighted estimates have been annualized by taking the average over the four-year study period. The observed to expected ratio (also known as lift) is the observed prevalence of the combination divided by the expected prevalence of the combination if each disease within the combination were statistically independent. 
Table 3: Frequent Combinations of Multimorbidity among U.S. Adults, Ranked by Average Medical Expenditures, 2016 2019

\begin{tabular}{|c|c|c|c|c|c|c|c|}
\hline Rank & Combination of Chronic Conditions & $\begin{array}{l}\text { No. of } \\
\text { cond- } \\
\text { itions }\end{array}$ & $\begin{array}{l}\text { Weighted } \\
\text { No. of } \\
\text { Adults } \\
\text { (in } \\
\text { millions) }\end{array}$ & $\begin{array}{c}\text { No. in } \\
\text { unweighted } \\
\text { sample }\end{array}$ & $\begin{array}{l}\text { Mean Annual Medical } \\
\text { Expenditures (95\% CI) }\end{array}$ & $\begin{array}{c}\text { Percent } \\
\text { Increase } \\
\text { Over } \\
\text { Highest } \\
\text { Superset }\end{array}$ & $\begin{array}{c}\text { Median } \\
\text { Annual } \\
\text { Medical } \\
\text { Expenditures }\end{array}$ \\
\hline 1 & $\begin{array}{l}\text { Diabetes \& Urinary problems \& } \\
\text { Cardiovascular disease }\end{array}$ & 3 & 1.13 & 477 & $\$ 35,782(\$ 31,129-\$ 40,435)$ & 23.1 & $\$ 21,608$ \\
\hline 2 & Diabetes \& Heart Failure & 2 & 1.02 & 410 & $\$ 35,125(\$ 29,813-\$ 40,437)$ & 36.1 & $\$ 18,950$ \\
\hline 3 & $\begin{array}{l}\text { Hypertension \& Cardiovascular disease \& } \\
\text { Heart Failure }\end{array}$ & 3 & 1.15 & 427 & $\$ 33,882(\$ 29,210-\$ 38,554)$ & 1.3 & $\$ 18,743$ \\
\hline 4 & Diabetes \& Arthritis \& Cardiovascular disease & 3 & 1.06 & 446 & $\$ 33,856(\$ 30,005-\$ 37,707)$ & 16.4 & $\$ 23,850$ \\
\hline 5 & $\begin{array}{l}\text { Diabetes \& Stomach problems \& } \\
\text { Cardiovascular disease }\end{array}$ & 3 & 1.05 & 444 & $\$ 33,823(\$ 29,942-\$ 37,704)$ & 16.3 & $\$ 22,992$ \\
\hline 6 & Cardiovascular disease \& Heart Failure & 2 & 1.42 & 526 & $\$ 33,451(\$ 29,034-\$ 37,868)$ & 29.6 & $\$ 18,720$ \\
\hline 7 & $\begin{array}{l}\text { Hypertension \& Musculoskeletal condition \& } \\
\text { Diabetes \& Urinary problems }\end{array}$ & 4 & 1.04 & 439 & $\$ 33,207(\$ 28,614-\$ 37,801)$ & 4.7 & $\$ 23,058$ \\
\hline 8 & $\begin{array}{l}\text { Musculoskeletal condition \& Diabetes \& } \\
\text { Cardiovascular disease }\end{array}$ & 3 & 1.24 & 508 & $\$ 32,345(\$ 28,190-\$ 36,499)$ & 11.2 & $\$ 20,053$ \\
\hline 9 & $\begin{array}{l}\text { Musculoskeletal condition \& Diabetes \& } \\
\text { Urinary problems }\end{array}$ & 3 & 1.34 & 559 & $\$ 31,711(\$ 27,927-\$ 35,494)$ & 22.4 & $\$ 21,787$ \\
\hline 10 & $\begin{array}{l}\text { Diabetes \& Asthma/COPD \& Stomach } \\
\text { problems }\end{array}$ & 3 & 1.08 & 469 & $\$ 31,674(\$ 28,038-\$ 35,309)$ & 25.4 & $\$ 21,295$ \\
\hline 11 & $\begin{array}{l}\text { Hypertension \& Hyperlipidemia \& Heart } \\
\text { Failure }\end{array}$ & 3 & 1.45 & 539 & $\$ 31,532(\$ 27,782-\$ 35,282)$ & 7.3 & $\$ 16,634$ \\
\hline 12 & $\begin{array}{l}\text { Musculoskeletal condition \& Stomach } \\
\text { problems \& Cardiovascular disease }\end{array}$ & 3 & 1.16 & 460 & $\$ 31,175(\$ 27,542-\$ 34,809)$ & 12.5 & $\$ 18,853$ \\
\hline 13 & $\begin{array}{l}\text { Musculoskeletal condition \& Urinary } \\
\text { problems \& Cardiovascular disease }\end{array}$ & 3 & 1.03 & 398 & $\$ 31,017(\$ 26,496-\$ 35,538)$ & 14.1 & $\$ 19,821$ \\
\hline 14 & $\begin{array}{l}\text { Hypertension \& Hyperlipidemia \& Diabetes \& } \\
\text { Cancer }\end{array}$ & 4 & 1.19 & 447 & $\$ 30,820(\$ 25,151-\$ 36,488)$ & 1.6 & $\$ 14,546$ \\
\hline 15 & $\begin{array}{l}\text { Hyperlipidemia \& Cardiovascular disease \& } \\
\text { Cancer }\end{array}$ & 3 & 1.36 & 492 & $\$ 30,496(\$ 26,375-\$ 34,617)$ & 3.1 & $\$ 17,045$ \\
\hline
\end{tabular}




\begin{tabular}{|c|c|c|c|c|c|c|c|}
\hline 16 & Hyperlipidemia \& Diabetes \& Cancer & 3 & 1.37 & 522 & $\$ 30,345(\$ 24,525-\$ 36,164)$ & 11.5 & $\$ 14,604$ \\
\hline 17 & $\begin{array}{l}\text { Hypertension \& Hyperlipidemia \& } \\
\text { Cardiovascular disease \& Cancer }\end{array}$ & 4 & 1.09 & 393 & $\$ 29,972(\$ 25,722-\$ 34,221)$ & -1.7 & $\$ 17,395$ \\
\hline 18 & $\begin{array}{l}\text { Hypertension \& Hyperlipidemia \& } \\
\text { Asthma/COPD \& Cardiovascular disease }\end{array}$ & 4 & 1.50 & 591 & $\$ 29,915(\$ 26,359-\$ 33,471)$ & 3.3 & $\$ 19,539$ \\
\hline 19 & $\begin{array}{l}\text { Hypertension \& Hyperlipidemia \& Diabetes \& } \\
\text { Cardiovascular disease }\end{array}$ & 4 & 2.77 & 1,156 & $\$ 29,885(\$ 26,978-\$ 32,792)$ & 2.0 & $\$ 16,486$ \\
\hline 20 & $\begin{array}{l}\text { Hyperlipidemia \& Musculoskeletal condition } \\
\text { \& Diabetes \& Stomach problems }\end{array}$ & 4 & 1.04 & 453 & $\$ 29,786(\$ 26,293-\$ 33,278)$ & 6.5 & $\$ 18,266$ \\
\hline 21 & $\begin{array}{l}\text { Hypertension \& Diabetes \& Arthritis \& } \\
\text { Stomach problems }\end{array}$ & 4 & 1.03 & 453 & $\$ 29,681(\$ 25,468-\$ 33,894)$ & 1.7 & $\$ 17,309$ \\
\hline 22 & Cardiovascular disease \& Cancer & 2 & 2.14 & 784 & $\$ 29,582(\$ 26,317-\$ 32,848)$ & 33.1 & $\$ 16,646$ \\
\hline 23 & $\begin{array}{l}\text { Hypertension \& Hyperlipidemia \& Urinary } \\
\text { problems \& Cardiovascular disease }\end{array}$ & 4 & 1.70 & 644 & $\$ 29,551(\$ 26,204-\$ 32,899)$ & 3.6 & $\$ 17,866$ \\
\hline 24 & Diabetes \& Stroke & 2 & 1.13 & 472 & $\$ 29,457(\$ 25,015-\$ 33,898)$ & 24.8 & $\$ 17,621$ \\
\hline 25 & Hyperlipidemia \& Heart Failure & 2 & 1.75 & 657 & $\$ 29,392(\$ 26,183-\$ 32,601)$ & 13.9 & $\$ 15,905$ \\
\hline
\end{tabular}

Table 3 Caption: Top 25 multi-way combinations of chronic disease ranked by average medical expenditures from the 2016-2019 Medical Expenditure Panel Survey (MEPS). Weighted means and 95\% confidence intervals were calculated by applying population weights using Taylorseries methods (i.e. complex survey methods) to account for the complex sampling design of the MEPS. Weighted estimates have been annualized by taking the average over the four-year study period. Percent Increase Over Highest Superset represents the percentage increase in cost per capita that that disease combination has over any simpler combination. 
Table 4: Association of Frequent Combinations of Multimorbidity with Perceived Fair or Poor Health Status, 2016 - 2019

\begin{tabular}{|c|c|c|c|c|c|c|c|c|}
\hline Rank & Combination of Chronic Disease & $\begin{array}{l}\text { No. of } \\
\text { cond- } \\
\text { itions }\end{array}$ & $\begin{array}{l}\text { Weighted } \\
\text { No. of } \\
\text { Adults (in } \\
\text { millions) } \\
\end{array}$ & $\begin{array}{c}\text { No. in } \\
\text { unweighted } \\
\text { sample } \\
\end{array}$ & $\begin{array}{l}\text { Percent } \\
\text { reporting } \\
\text { fair or } \\
\text { poor } \\
\text { health }\end{array}$ & $\begin{array}{c}\text { Percent } \\
\text { increase } \\
\text { over } \\
\text { highest } \\
\text { superset }\end{array}$ & $\begin{array}{c}\text { Unadjusted } \\
\text { Odds Ratio } \\
(95 \% \text { CI })\end{array}$ & $\begin{array}{l}\text { Adjusted Odds } \\
\text { Ratio }(95 \% \text { CI })\end{array}$ \\
\hline 1 & Diabetes \& Asthma/COPD \& Arthritis & 3 & 1.18 & 321 & 62.9 & 12.6 & $10.1(8.1-12.7)$ & $6.9(5.4-8.8)$ \\
\hline 2 & Musculoskelatal \& Diabetes \& Asthma/COPD & 3 & 1.36 & 362 & 63.2 & 12.9 & $9.5(7.8-11.6)$ & $6.6(5.4-8.1)$ \\
\hline 3 & $\begin{array}{l}\text { Musculoskelatal \& Diabetes \& } \\
\text { Depression/Anxiety }\end{array}$ & 3 & 1.08 & 282 & 61.0 & 13.6 & $8.3(6.5-10.7)$ & $6.2(4.7-8.0)$ \\
\hline 4 & Diabetes \& Asthma/COPD \& Stomach problems & 3 & 1.08 & 293 & 62.5 & 11.9 & $8.9(7.1-11.1)$ & $6.2(4.9-7.8)$ \\
\hline 5 & $\begin{array}{l}\text { Depression/Anxiety \& Asthma/COPD \& } \\
\text { Arthritis }\end{array}$ & 3 & 1.00 & 255 & 60.4 & 17.4 & $8.1(6.3-10.4)$ & $6.1(4.7-7.9)$ \\
\hline 6 & $\begin{array}{l}\text { Musculoskelatal \& Depression/Anxiety \& } \\
\text { Asthma/COPD }\end{array}$ & 3 & 1.56 & 369 & 58.4 & 14.5 & $7.4(5.9-9.2)$ & $6.0(4.8-7.6)$ \\
\hline 7 & $\begin{array}{l}\text { Depression/Anxiety \& Asthma/COPD \& } \\
\text { Stomach problems }\end{array}$ & 3 & 1.04 & 253 & 59.0 & 15.3 & $7.4(5.7-9.5)$ & $5.9(4.6-7.7)$ \\
\hline 8 & Diabetes \& Heart Failure & 2 & 1.02 & 237 & 57.8 & 25.6 & $8.4(6.4-11.1)$ & $5.6(4.2-7.4)$ \\
\hline 9 & $\begin{array}{l}\text { Hyperlipidemia \& Depression/Anxiety \& } \\
\text { Asthma/COPD }\end{array}$ & 3 & 1.39 & 323 & 57.6 & 13.3 & $7.5(6.0-9.5)$ & $5.5(4.3-7.0)$ \\
\hline 10 & Diabetes \& Asthma/COPD & 2 & 3.66 & 838 & 55.0 & 34.9 & $7.4(6.5-8.5)$ & $5.3(4.6-6.1)$ \\
\hline 11 & Musculoskelatal \& Diabetes \& Arthritis & 3 & 1.79 & 431 & 57.2 & 13.9 & $7.8(6.4-9.4)$ & $5.3(4.4-6.5)$ \\
\hline 12 & Diabetes \& Arthritis \& Cardiovascular disease & 3 & 1.06 & 260 & 58.3 & 15.5 & $8.1(6.2-10.7)$ & $5.2(3.9-6.9)$ \\
\hline 13 & $\begin{array}{l}\text { Hypertension \& Depression/Anxiety \& } \\
\text { Asthma/COPD }\end{array}$ & 3 & 1.79 & 413 & 56.8 & 12.1 & $7.0(5.7-8.6)$ & $5.2(4.2-6.4)$ \\
\hline 14 & Diabetes \& Stroke & 2 & 1.13 & 260 & 55.1 & 15.5 & $7.9(6.4-9.8)$ & $5.2(4.1-6.5)$ \\
\hline 15 & Musculoskelatal \& Asthma/COPD \& Arthritis & 3 & 1.87 & 418 & 55.2 & 10.9 & $7.0(5.9-8.5)$ & $5.1(4.2-6.1)$ \\
\hline 16 & $\begin{array}{l}\text { Diabetes \& Urinary problems \& Cardiovascular } \\
\text { disease }\end{array}$ & 3 & 1.13 & 271 & 56.8 & 14.9 & $7.8(6.0-10.1)$ & $5.0(3.9-6.6)$ \\
\hline 17 & Diabetes \& Arthritis \& Stomach problems & 3 & 1.24 & 303 & 56.6 & 13.0 & $7.5(6.0-9.4)$ & $5.0(4.0-6.3)$ \\
\hline 18 & Asthma/COPD \& Cardiovascular disease & 2 & 2.93 & 603 & 53.7 & 30.3 & $7.5(6.4-8.8)$ & $5.0(4.3-5.8)$ \\
\hline 19 & $\begin{array}{l}\text { Diabetes \& Stomach problems \& Cardiovascular } \\
\text { disease }\end{array}$ & 3 & 1.05 & 250 & 56.3 & 14.1 & $7.5(6.0-9.5)$ & $5.0(3.9-6.3)$ \\
\hline 20 & Diabetes \& Depression/Anxiety & 2 & 3.04 & 639 & 52.7 & 32.1 & $6.4(5.6-7.5)$ & $4.9(4.2-5.7)$ \\
\hline 21 & Musculoskelatal \& Diabetes \& Stomach & 3 & 1.47 & 353 & 56.1 & 15.0 & $7.1(5.9-8.6)$ & $4.9(4.0-5.9)$ \\
\hline
\end{tabular}




\begin{tabular}{|c|c|c|c|c|c|c|c|c|}
\hline & problems & & & & & & & \\
\hline 22 & $\begin{array}{l}\text { Musculoskelatal \& Diabetes \& Urinary } \\
\text { problems }\end{array}$ & 3 & 1.34 & 307 & 54.9 & 13.1 & $7.3(5.9-9.1)$ & $4.9(3.9-6.1)$ \\
\hline 23 & Cardiovascular disease \& Stroke & 2 & 1.10 & 239 & 53.8 & 13.5 & $7.8(6.1-9.9)$ & $4.9(3.8-6.2)$ \\
\hline 24 & Diabetes \& Arthritis \& Urinary problems & 3 & 1.08 & 254 & 55.2 & 10.8 & $7.5(5.9-9.4)$ & $4.8(3.8-6.2)$ \\
\hline 25 & Depression/Anxiety \& Asthma/COPD & 2 & 3.88 & 730 & 49.9 & 30.7 & $5.4(4.7-6.3)$ & $4.8(4.2-5.6)$ \\
\hline
\end{tabular}

Table 4 Caption: Top 25 multi-way combinations of chronic disease ranked by highest percent of population self-reporting fair or poor health from the 2016-2019 Medical Expenditure Panel Survey (MEPS). Weighted percent, odds ratio, adjusted odds ratios, and 95\% confidence intervals were calculated by applying population weights using Taylor-series methods (i.e. complex survey methods) to account for the complex sampling design of the MEPS. Weighted estimates have been annualized by taking the average over the four-year study period. Percent Increase Over Highest Superset represents the percentage increase in cost per capita that that disease combination has over any simpler combination. Adjusted odds ratios were calculated using log-binomial models adjusting for age, race, and sex, and Taylor-series methods for standard errors. 